\title{
DDT in Crassostrea virginica (Gmelin, 1791) of Coastal Lagoons in the Gulf of Mexico
}

\author{
Ma del Refugio Castañeda-Chávez \\ Instituto Tecnológico de Boca del Río. División de Estudios de Posgrado e Investigación \\ Km.12 Carretera Veracruz-Córdoba. Boca del Río, C.P. 94290, Ver. México \\ Tel: 1-(229)-986-0189 Ext. 113 E-mail: castanedaitboca@yahoo.com.mx \\ Fabiola Lango-Reynoso \\ Instituto Tecnológico de Boca del Río. División de Estudios de Posgrado e Investigación \\ Km.12 Carretera Veracruz-Córdoba. Boca del Río, C.P. 94290, Ver. México \\ E-mail: fabiolalango@yahoo.com.mx
}

Cesáreo Landeros-Sánchez (Corresponding author)

Colegio de Posgraduados, Campus Veracruz

Apartado postal 421 Veracruz, Ver. México

Tel: 1-(229)-201-0770Ｅ-mail: clandero@colpos.mx

\begin{abstract}
Extensive use of Dichloro-diphenyl-trichloroethane (DDT) has resulted in noticeable accumulation of the compound in aquatic trophic webs or food chains within tropical and subtropical areas of the Gulf of Mexico, causing public health concerns. The objective of this research was to assess levels of DDT and its metabolites in Crassostrea virginica (Gmelin, 1791) of four coastal lagoons (Tamiahua, Vega de Alatorre, La Mancha and Alvarado) located in the Gulf of Mexico. Oysters were collected from each of the four lagoons during summer (rainy), winter (windy), and spring (dry). Each sample consisted of 100 oysters, and the concentrations of DDT and its metabolites were quantified. Total DDT concentrations (ng/g) in oysters were 53.893 in Alvarado, 99.470 in La Mancha, 103.850 in Vega de Alatorre, and 114.737 in Tamiahua, indicating the lagoons were contaminated with DDT. It is concluded that the studied lagoon systems are contaminated by DDT.
\end{abstract}

Keywords: Oyster, DDT, Metabolite, Contamination, Lagoon

\section{Introduction}

In Mexico, 276 chemical ingredients are used to produce two thousand commercial pesticides; from which $50 \%$ are insecticides and the other half are fungicides and herbicides. Half of the insecticides are organochlorine based and are used in public health campaigns and agriculture, while the other $50 \%$ are organophosphates, carbamates, and pyrethroids (CICOPLAFEST, 1994). Organochlorine pesticides are insoluble in polar solvents, are soluble in low polarity solvents, are chemically and biochemically stable, and have half-lives greater than 10 years. In many cases, their byproducts from degradation are more stable that the original compound (Botello et al., 2004). Organochlorine pesticides are classified into four groups depending on their structure (Sonowane, 1995): (a) cycloalkane chloride metabolites such as Hexachlorocyclohexane ( $\mathrm{HCH})$, hidrocarbure ciclodieno chloride; (b) metabolites such as Aldrin, Dieldrin, Endrin, Heptachloro, Endosulfan, Clordane, and Mirex; (c) chlorinated terpenes such as Toxaphene; and (d) the halogenade derived from aromatic hidrocarbure. The most important compound of this group is Dichloro-diphenyl-trichloroethane (DDT), a highly persistent organochlorine pesticide. The toxic agent is an isomer complex mixture: $p p^{\prime}$-DDT (77.1\%) which has important insecticidal properties, $o p^{\prime}$-DDE (0.1\%), $o p^{\prime}$-DDT (14.9\%), $p p^{\prime}$-DDE (4\%), $p p^{\prime}$-DDD (0.3\%), and $o p^{\prime}$-DDD $(0.1 \%)$, as well as unidentified compounds $(3.5 \%)$.

DDT has been used for decades as the primary pesticide to control the vector of malaria and other vector transmitted diseases. Early commercial applications were very successful, yet malaria continues to affect society, with nearly 2.5 million people in 90 countries at risk of acquiring the disease each year (Diaz, 2000). In the state 
of Veracruz, Plasmodium is present in swampy and unhealthy areas, and $2 \mathrm{~g} / \mathrm{m}^{2}$ of DDT was sprayed twice a year on waters and communities by the Public Health Department (SSA, 1994). The dosage was recommended by the International Health Organization (IHO); however, DDT may be used when safe and effective alternatives are not available in this country (WHO, 1984; Program for vector control in the VIII-PHD Region-SSA, 1997; Dzul et al., 2007).

\subsection{DDT Toxicokinetics}

In developing countries, human exposure to DDT and its metabolites occurs primarily by consuming contaminated food and water. However, the inhalations of emissions during spraying and dermal absorption can also be significant routes of contamination, especially for pregnant women, a situation common in countries such as Mexico (Jury et al., 1983; Matthies et al., 1991).

\subsection{Biomagnification of DDT in the trophic web}

DDT toxicity, as with other organochlorine compounds, is due to a stable chemical structure that is hydrophobic, making it highly resistant to biodegradation in extreme environments. It is harmful to organisms due to the persistence of its residues, routes of dispersion, and its bioaccumulation and biomagnification throughout the trophic web, eventually harming human health (Young et al., 1988).

In tropical regions, DDT dispersion is magnified by its volatility, affecting society at local and global scales. During spraying, this pesticide and its metabolites volatilize under high temperatures, and disperse over large areas, remaining in the atmosphere and eventually entering water and soil at local and large scales (Larson et al., 1995). The transfer of DDT to food sources is complex because it occurs through numerous processes that depend on DDT concentration dynamics in the animal or plant, time of exposure, pesticide kinetics and metabolization, position of the organism in the trophic web, metabolic characteristics of the organism, species, sex, body size, amount of lipid storage in the body, and environmental characteristics and conditions of the contaminated locality.

Within regional communities, organochlorine pesticides have been detected in meat and fat of cattle (Waliszewski et al., 1996); DDT and HCH in the adipose tissue of human cadavers, and in the milk of cattle (Waliszewski et al., 1995; Pardio et al., 2003; Waliszewski et al., 2000); and DDT in adipose tissue, serum and milk of lactating women (Waliszewski et al., 2000). In addition, these regions receive discharge from anthropogenic activities and pluvial discharges from neighboring states such as Puebla. Hence, there is a persistence of organochlorine pesticides in wheat and the soils where this grain is cultivated (Waliszewski et al., 2003), and the same effect has been observed in aquatic organisms such as shrimp (Castañeda et al., 2004), tropical crabs (Gamboa, 2008), and oysters (Castañeda et al., 2006). Positive correlations have been reported between breast carcinomas in women and pesticides, supporting the negative effect of these pesticides on human health (Waliszewski et al., 2003).

The use of organochlorine pesticides in Veracruz and the surrounding region, particularly the use of DDT to control mosquitoes that transmit dengue and malaria, contributes to the dispersion of the pesticides that contaminate aquatic organisms. In lagoons from the region, the American oyster, Crassostrea virginica, is the dominant oyster species, and is economically important (Carta Nacional Pesquera, 2006). Based on these facts, the objective of this research was to assess levels of DDT and its metabolites in Crassostrea virginica (Gmelin, 1791) of four coastal lagoons (Tamiahua, Vega de Alatorre, La Mancha and Alvarado) located in the Gulf of Mexico.

\section{Materials and Methods}

\subsection{Studied area and geographical location of lagoon systems}

The state of Veracruz is located on the Gulf Coast of Mexico, between $17^{\circ} 08^{\prime}$ and $22^{\circ} 28^{\prime}$ North latitude and $93^{\circ} 35^{\prime}$ and $98^{\circ} 38^{\prime}$ 'West longitude. It borders the state of Tamaulipas to the north, San Luis Potosi, Hidalgo, and Puebla to the west, and Oaxaca, Chiapas, and Tabasco to the south and southeast (INEGI, 1999). The location of the Tamiahua, Vega de Alatorre, La Mancha and Alvarado lagoon systems are displayed in Figure 1.

La Mancha system is located between $19^{\circ} 34^{\prime \prime}$ and $19^{\circ} 42^{\prime \prime}$ North latitude and between $96^{\circ} 23^{\prime \prime}$ and $96^{\circ} 27^{\prime \prime}$ East longitude, and is 156.74 ha in size; Alvarado system is located southwest Veracruz, between $18^{\circ} 44^{\prime}$ and $18^{\circ} 52^{\prime}$ North latitude and $95^{\circ} 44^{\prime}$ and $95^{\circ} 57^{\prime}$ 'West longitude (Flores-Coto \& Mendez-Vargas, 1982) and is composed of the lagoons Camaronera, Buen País, Alvarado and Tlalixcoyan, and is 11800 ha in size; the Tamiahua system is located between $21^{\circ} 06^{\prime}$ North latitude and $97^{\circ} 23^{\prime}$ and $97^{\circ} 46^{\prime}$ ' West longitude, it is supplied from the north by the Pánuco River and from the south by the Tuxpan River, and is 88000 ha in size (Castañeda \& Contreras, 1994). Lastly, the Vega de Alatorre system is located between $20^{\circ} 02^{\prime}$ and $20^{\circ} 06^{\prime}$ North latitude and $96^{\circ} 36^{\prime}$ and $96^{\circ} 42^{\prime}$ 
West longitude, and it is composed of two water bodies, Laguna Chica and Laguna Grande, and is 2250 ha in size.

\subsection{Lagoon system evaluation}

Oyster samples were collected during the winter (windy-dry), spring (dry), and summer (rainy) from September 2001 through September 2002, in La Mancha and Alvarado, and from January to December 2004 in Tamiahua and the Vega de Alatorre systems. A sampling site was located in each system where the presence of $C$. virginica was spatially continuous (oyster banks). There was one sampling site per lagoon except for the Alvarado system which had two (Figure 1). A sample of 100 oysters of market size $(7.0 \pm 3.0 \mathrm{~cm})$ was collected each sampling period from each site by free diving. Oysters were cleaned to remove waste and attached algae, composited into one bag for each site, and brought to a laboratory under cool temperatures according to protocol NOM-109-SSA1-1994 (SSA, 2003). Shelled oysters (flesh and juice) were placed in labeled Ziplock ${ }^{\circledR}$ plastic bags and frozen at $-40^{\circ} \mathrm{C}$ for determination of DDT and metabolite concentrations.

\subsection{DDT and its metabolites}

\subsubsection{Material preparation}

The glassware was prepared according to pesticide residue analysis guidelines Waliszewki et al. (2008). All glassware was first washed with tap water and then with distilled water, petroleum ether, and acetone, to prevent cross contamination from processed samples. To ensure absence of any source of sample contamination, the petroleum ether used to wash glassware was constantly assessed using gas chromatography. Samples were analyzed using hexane with a $40-50{ }^{\circ} \mathrm{C}$ boiling range (analytical grade, Backer-México); powdered sodium sulphate (Backer-México) previously activated and purified in a furnace at $650{ }^{\circ} \mathrm{C}$ for 16 hours; and $95-97 \%$ sulfuric acid (analytical grade, Merck-México). For quality control, readings from the chromatograph for each pesticide were adjusted by linear regression to the 5-point curves calibrated previously. Standard samples for curve adjustments were performed using ChemStation HP 3398A (ChemService, Inc., West Chester, 19381 Pennsylvania, USA). A fortified test was carried out resulting in a recovery of $93 \%$.

\subsubsection{Sample Analysis}

Analyses were performed according to Murphy (1972) and Waliszewski et al. (2008). Samples were defrosted, oven-dried at $80^{\circ} \mathrm{C}$ for 24 hours, and then ground using a porcelain mortar and pestle. Ten grams of each dried and ground sample was then rotary evaporated with hexane using the Soxhlet method for 4 hours. The extract was then filtered over $2 \mathrm{~g}$ of sodium sulfate and concentrated to $40 \mathrm{ml}$ by rotary evaporation at $45^{\circ} \mathrm{C}$. A $20 \mathrm{ml}$ sample of the extract was evaporated to complete dryness to eliminate the solvent and was weighed to determine lipid content by gravimetric method. An additional 10-ml sample from the concentrated extract was placed in a $50 \mathrm{ml}$ tube with a baquelite cap, and $1 \mathrm{ml}$ of sulfuric acid was added. The tube was vigorously shaken for $1 \mathrm{~min}$ to precipitate fat, and was left to rest for $15 \mathrm{~min}$ to separate phases. The supernatant was filtered over a layer of sodium sulfate (3.0-4.0 g), washed using $10 \mathrm{ml}$ of petroleum ether, and then reduced by evaporation to $1 \mathrm{ml}$, and placed in vials for liquid-gas chromatographic analysis. Three replicates from each sample were analyzed. An Agilent Chromatographer HP 6890 Plus equipped with an autosampler was used under the following conditions: $\mu$ ECD $330{ }^{\circ} \mathrm{C}$ of the detector with electron capture, $250{ }^{\circ} \mathrm{C}$ injector temperature in split-less mode, oven temperature programmed from 85 to $195{ }^{\circ} \mathrm{C}$ at $30^{\circ} \mathrm{C} \mathrm{min}^{-1}$, and 195 to $250{ }^{\circ} \mathrm{C}$ at $5{ }^{\circ} \mathrm{C} \mathrm{min}{ }^{-1}$ sustained for $5 \mathrm{~min}$, using a column HP 608 at $30 \mathrm{~m} \times 0.053 \mathrm{~mm}$ D.I. and $0.05 \mathrm{~m}$ film. Ultrapure nitrogen was used as carrier at $2 \mathrm{ml}$ $\min ^{-1}$ constant flux. Three subsamples were analyzed using a volume of $1.0 \mu \mathrm{l}$ per injection.

Quantitative and qualitative analyses were performed by comparing retention times and areas under the curve with those from reference standards used during equipment calibration. Results are presented based on the extracted lipids in ng/g (lipid base). Values of $p p^{\prime}$ - DDT/ pp'- DDE (Zumbado et al., 2004) were calculated based on the annual mean of each lagoon system as an index of chronic environmental exposure to DDT (Ahlborg et al., 1995).

\section{Results}

Results are presented for each season and sampling period. Even though climatic, hydrological, edaphic, biological, and anthropogenic conditions differed among sites, results from two sites are presented in the same table when samplings occurred in the same season.

\subsection{Alvarado and La Mancha systems}

Table 1 shows the mean detectable $p p^{\prime}$-DDT values from the three sampling seasons in Alvarado lagoon. The highest average concentration of $p p^{\prime}$-DDT in oyster samples $(4.407 \mathrm{ng} / \mathrm{g}$ ) was observed in summer (the rainy season) in Alvarado (Table 1). Although pp'-DDT was not detected in samples from La Mancha, the highest 
average concentration of $p p^{\prime}$-DDE was observed in samples collected from La Mancha during the dry season $(48.860 \mathrm{ng} / \mathrm{g})$, while samples from Alvarado were the lowest $(12.230 \mathrm{ng} / \mathrm{g})$ during the wet season. The highest average concentration of $p p^{\prime}$-DDD was recorded from La Mancha during the windy season (29.780 ng/g), while the lowest value $(8.500 \mathrm{ng} / \mathrm{g})$ was recorded from Alvarado during the wet season.

Total DDT concentrations in oyster tissue samples were significantly different $(\mathrm{P}<0.05)$ between La Mancha and Alvarado for the three sampling seasons. The highest average concentration was reported from La Mancha $(117.230 \mathrm{ng} / \mathrm{g})$ during the dry season, while the lowest value $(41.430 \mathrm{ng} / \mathrm{g})$ was reported from Alvarado during the rainy period.

\subsection{Tamiahua and Vega de Alatorre Systems}

Average concentrations of DDT and its metabolites were higher in oysters sampled from Vega de Alatorre than those sampled from Tamihua (Table 2).

The highest average concentration of $p p^{\prime}$-DDT was observed in oyster tissues sampled from Tamiahua lagoon $(13.628 \mathrm{ng} / \mathrm{g})$ during the dry season, while the lowest average concentration $(2.042 \mathrm{ng} / \mathrm{g})$ occurred in Vega de Alatorre during the same period. The highest average concentration of $p p^{\prime}-\mathrm{DDE}(52.878 \mathrm{ng} / \mathrm{g})$ was observed in oyster tissue samples from Vega de Alatorre during the wet season, while the lowest average concentration $(17.187 \mathrm{ng} / \mathrm{g})$ was observed during the windy season in this lagoon. The highest total DDT concentration $(138.293 \mathrm{ng} / \mathrm{g})$ was observed in oyster samples from this same lagoon during the wet period.

We found significant differences $(\mathrm{P}<0.05)$ among the concentrations of DDT and their metabolites in oyster samples between the two lagoon systems and among the sampling periods.

\subsection{Quotient $D D T / D D E$}

Table 3 contains values of the quotient DDT/DDE for all four lagoons.

\section{Discussion}

Coastal lagoons are characterized as being connected with the ocean through one or more river mouths to permit a continuous influx and efflux of marine water to maintain equilibrium. La Mancha, the smallest of the four lagoons studied (156.74 ha), has a coastal mouth that is filled with debris that interferes with adequate interchange of water. As such, contaminants such as DDT and its metabolites accumulate in sediments where they can be absorbed by benthic organisms such as the oyster, C. virginica (Wang et al., 2008). As well, Tamiahua lagoon is the largest in the state of Veracruz (88 $000 \mathrm{ha}$ ), and also suffers from low water circulation and interchange because the two mouths connecting the system (Corazones and Tampachici) are clogged with debris, promoting accumulation of high concentrations of DDT and its metabolites. This situation has, on occasion, caused productive oyster beds in the northeastern part of the lagoon system to be buried in sediment (INAPESCA, 2009).

\section{$4.1 \mathrm{pp}-D D T$}

In only three of the four lagoons studied (Tamiahua, Vega de Alatorre, and Alvarado) were concentrations of $p p^{\prime}-D D T$ detected during all three sampling periods (Tables 1,2$)$. The highest value (13.628 $\mathrm{ng} / \mathrm{g}$ lipid base) was observed in Tamiahua lagoon during the dry period, suggesting that the surrounding area had been treated with DDT to control malaria and dengue fever vectors, and that wind and rainwater runoff had transported much of the DDT to the lagoons (IPCS, 1989).

Mean annual concentrations of $p p^{\prime}$-DDT in C. virginica from the four lagoons (Table 3) ranged from 53.890 to $114.737 \mathrm{ng} / \mathrm{g}$, indicating a high persistence of DDT and its metabolites from bioaccumulation. Studies performed in other countries have also assessed levels of DDT contamination in bivalve mollusks. The species $C$. rhizophorae from southern France has been reported to contain $0.04 \mathrm{ng} / \mathrm{g}$ of DDT in a lipid base (Pellerin, 1992), and $16 \mathrm{ng} / \mathrm{g}$ in studies performed in Turkey (Barlas, 1999).

However, studies performed in Latin America and the United States have reported total DDT concentrations in oysters to be higher than those in this study. Research in Argentina has shown oysters to contain $210 \mathrm{ng} / \mathrm{g}$ (lipid base), and researchers from Brasil, Chile, Ecuador and El Salvador have reported 120, 140, 160 and $180 \mathrm{ng} / \mathrm{g}$ of DDT (lipid base), respectively. In San Andres Bay and Alabama (USA), mussels were shown to contain 160 and $960 \mathrm{ng} / \mathrm{g}$ of DDT (Sericano et al., 1995), and in mussels from New Jersey (USA) the total DDT concentration in lipid base ranged from 25 to $300 \mathrm{ng} / \mathrm{g}$ (Kennish and Ruppel, 1996). In San Quintin Bay in northeast Mexico, Gutierrez et al., (1984) reported $21.5 \mathrm{ng} / \mathrm{g}$ of total DDT in C. gigas, and in lagoons in the Gulf of Mexico, Rosales et al., (1979) and Botello (1990) found DDT concentrations of $9.0 \mathrm{ng} / \mathrm{g}$ (lipid base) in C. virginica, a value lower than those found in the present study. 


\section{2 $p p^{\prime}-D D E$}

The presence of $p p^{\prime}-D D E$ in all studied lagoons revealed the existence of a source of DDT contamination that is negatively impacting water quality. The concentrations in each sampling season could mean that DDT was used recently in the surrounding areas to control pests. However, the long term persistence of this contaminant in the lagoons, as reflected in the DDT/DDE values (Table 3) which are lower than 1.0, indicates that the lagoons and their surroundings have been chronically exposed to organochlorate pesticides, and that DDT has been metabolized to DDE by macro- and microorganisms (Zumbado et al., 2004; Syasina, 2003). Consequently, the oyster, $C$. virginica, has been exposed to DDT due to its position in the trophic web as a filter feeder, thus bioaccumulating and biomagnifying DDT and its metabolites in the systems. This situation represents a risk for all organisms in these trophic webs.

The $p p^{\prime}$-DDE annual mean concentrations in C. virginica in the four studied lagoons (Table 3) ranged from 17.690 to $39.570 \mathrm{ng} / \mathrm{g}$. In other studies performed in the Gulf of Mexico with the same species, concentrations of pp'-DDE have ranged from 0.42 to $9.0 \mathrm{ng} / \mathrm{g}$ in Laguna de Alvarado (Rosales et al., 1979 and Botello et al., 1990), $17.67 \mathrm{ng} / \mathrm{g}$ in Laguna de Términos (Gold et al., 1993), and $4.17 \mathrm{ng} / \mathrm{g}$ in Laguna del Carmen, Campeche (Albert, 1996). On the other hand, $6.46 \mathrm{ng} / \mathrm{g}$ have been reported in the oyster, C. gigas, from Baja California (Gutierrez et al., 1988), and $22.0 \mathrm{ng} / \mathrm{g}$ in C. corteziensis from Mazatlán (Páez, 1998). In our research, pp'-DDE concentrations were higher than those reported in the aforementioned studies, with the exception of Paez (1988), and also were higher than those in Ostrea edulis (13.48 ng/g) from Spain (ATSDR, 2002). In oysters from the Adriatic Sea, 2.1 and $18.3 \mathrm{ng} / \mathrm{g}$ of $p p^{\prime}$-DDT and $p p^{\prime}$-DDE (lipid base), respectively, have been reported (Hargrave and Philips, 1976).

\section{$4.3 p p^{\prime}-D D D$}

$p p^{\prime}$-DDD concentrations in the four lagoons were lower than those for $p p^{\prime}$-DDE, but higher that those for $p p$ '-DDT, and values ranged from 8.399 to $29.780 \mathrm{ng} / \mathrm{g}$ (Tables 1, 2). These concentrations are relatively high compared to those obtained for C. virginica $(1.28 \mathrm{ng} / \mathrm{g}$ ) in Laguna de Términos, Campeche, Mexico (Gold et al., 1993). This metabolite is often reported as not detected (e.g. Botello et al., 1990; Sericano et al., 1990a, b; Albert, 1996).

Presence of $p p$ '-DDD in the lagoons in this study could be explained based on the characteristics of the lagoon bottoms which have a high amount of organic matter that can be suspended (Kennish and Ruppel, 1996; Al-Ghadban et al., 1994; Calva et al., 2006). This condition is caused by natural water flow (overland and stream) that carries organic matter into the lagoons during the rainy season. These natural processes contribute to the exposure of C. virginica to DDT and its residuals which are stored in the adipose tissue (Ferreira and Vale, 2001). When DDT reaches the lagoons it has a low solubility in this environment, and the residuals will sediment out at different solubilities ( $p p^{\prime}$-DDT at $3.4 \mathrm{ppb}$ solubility; $p p^{\prime}$-DDE at $120 \mathrm{ppb}$ solubility; $p p^{\prime}$-DDD at $160 \mathrm{ppb}$ solubility) (ATSDR, 1994). Thus, a considerable amount of $p p^{\prime}$-DDD will stay in the water column, resulting in a greater exposure of $C$. virginica to this contaminant because oysters attach themselves to hard surfaces on the bottom and filter organic and inorganic matter suspended from the bottom where the chemical is bound. This could explain why $p p^{\prime}$-DDD concentrations observed in the lagoons from this study were so high (Extoxnet, 1993a, b).

\section{$4.4 o p^{\prime}-D D T$}

Concentrations of op'-DDT in C. virginica from all four systems are higher than the other observed DDT metabolites (Table 3). This finding is similar to results reported by Díaz (2000), Allen et al., (1997), Trirpenou et al., (1998), and Abd-Allah and Ali (1994) on research with arctic trout, dolphins from Greece, and sardines from Egypt, respectively. Yet, op'-DDT significantly differed among lagoons $(P<0.05)$ in all seasons. The highest mean concentration was observed in La Mancha during spring $(50.86 \mathrm{ng} / \mathrm{g})$, suggesting a slow exchange of water in the lagoon at this time. Furthermore, the lagoon's surface is smaller compared to the Alvarado lagoon and its coastal mouth was observed to be filled with debris that interferes with adequate interchange of water as mentioned before, resulting in higher concentrations of contaminants during this season (INAPESCA, 2009).

\subsection{Total $\Sigma D D T$}

Use of DDT by the Malaria Control Program in Mexico was reduced to $80 \%$ in 2000 (Caballero, 2001) and it was expected that its use would be completely prohibited by 2006 (COPs, 2004) and replaced by pyrethroid pesticides. Concentrations of DDT observed in this study are a result of the malaria control campaigns initiated in 1945, which became a general control form in 1956 (Stapleton, 1998; Fernandez De Castro, 1988). Due to anthropogenic activity, rain, and hydrological actions, DDT and its metabolites were deposited in the Gulf of 
Mexico. These contaminants can seriously alter the health and productivity of $C$. virginica in aquatic systems (Ley General del Equilibrio Ecológico y la Protección al Ambiente, 1988) by interfering with lipid metabolism, producing deficiencies of essential fatty acids, altering membrane structures, altering the structure and function of digestive glands, altering the proportion of sexes affect reproduction, and may even lead to local species extinction. In fact, exposure of $C$. virginica to DDT concentrations higher than $10 \mathrm{mg} / \mathrm{l}$ for $96 \mathrm{~h}$ can be lethal (Lowe et al., 1971; Marchand and Duursma, 1976; Farrington, 1983; Gutiérrez-Galindo et al., 1984; Phillips and Rainbow, 1994).

Consumption of aquatic organisms contaminated with DDT (such as C. virginica) is a great risk to public health, especially for people living along the Gulf of Mexico who include oysters as normal dietary item. Damage to human health from the consumption of contaminated oysters includes nervous system alterations, estrogenic disorders (Gellert et al., 1972; Soto et al., 1995), and endocrine system disorders (Colborn et al., 1993). Disorders caused by contaminants having estrogenic properties may be responsible for breast and hepatic cancers (Wolff et al., 2000; Snedecker, 2001; Glynn et al., 2003; Jaga and Dharmani, 2003; Zumbado et al., 2004).

\section{Conclusions}

Our results show that environmental contamination from DDT and its metabolites has accumulated in Crassostrea virginica in all four studied lagoons. The FDA (1984) established a $5 \mu \mathrm{g} / \mathrm{g}$ (dry base) as the maximum limit permitted in aquatic organisms used as food. In addition, the NOM-031-SSA1-1993 states that fresh or refrigerated mollusks must not contain any residuals of the pesticides prohibited in the pesticide catalogs, including DDT (Diario Oficial, 1995; CICOPLAFEST, 2004).

Relatively high DDT concentrations in Crassostrea virginica in the four lagoons are a result of chronic exposure to high concentrations of organochlorate pesticides in the lagoons from the Malaria Control Programs; an interpretation supported by the high DDT/DDE values in Table 3 which were lower than 1 (Zumbado et al., 2004; Syasina, 2003). Further, strong winds from the north ("nortes") are known to affect the Gulf of Mexico, and there is evidence that from 40 to $80 \%$ of the DDT used in mosquito control programs is volatilized (Plimmer, 1992; Albert and Benítez, 2005). A proportion of this quantity is easily carried by winds to the lagoons. Lastly, precipitation during the rainy season produces runoff that transports DDT applied to nearby crop fields before it was banned in 2000 (Albert and Benítez, 2005). Crassostrea virginica constitutes a large part of the bivalve fauna in the Gulf of Mexico, and is accumulating DDT residuals. This organism is used as a food source, and oyster consumers are at risk of suffering negative effects from this pesticide.

\section{Acknowledgements}

We thank Consejo Nacional de Ciencia y Tecnología (CONACYT) for financial support to research project CONACYT-SIGOLFO Clave 00-06-001-V "Evaluación de los bancos de ostión (Crassostrea virginica) en la Laguna de la Mancha, Veracruz", and for a grant to Dra. Fabiola Lango Reynoso through the program "Estancia Sabática Vinculada al Fortalecimiento de la Calidad del Posgrado Nacional 2008" which permitted research to be performed in Colegio de Postgraduados, Campus Veracruz. Finally, we thank Consejo del Sistema Nacional de Educación Tecnológica (COSNET) for cofunding this research through the Grant "COSNET 1252.01 Programa Ostión". We acknowledge the Instituto Tecnológico de Boca del Río and Colegio de Postgraduados, Campus Veracruz for support during the manuscript preparation under the collaboration agreement "Acuerdo General de Colaboración Académica" signed by both institutions in October 2006.

\section{References}

Ahlborg, U. G., Lipworth, L., Titus-Ernstoff, L., Hsieh, C. C., Hanberg, A., Baron, J., Trichopoulos, D. \& Adami, H.O. (1995). Organochlorines compounds in relations to breast cancer, endometrial cancer, and endometriosis an assessment of the biological and epidemiological evidence. Critical Review Toxicology, 25, 463-531.

Abd-Allah, A. M., A., \& Ali H. A. (1994). Residue levels of chlorinated hydrocarbons compounds in fish from El-Max Bay and Maryut Lake, Alexandria, Egypt. Toxicological and Environmental Chemistry, 42, 107-114.

Albert, L. A. \& Benítez, J. A. (2005). Impacto ambiental de los plaguicidas en los Ecosistemas Costeros. In Golfo de México Contaminación e Impacto Ambiental: Diagnostico y Tendencias. Botello, V.A., Rendón, J., Osten, G., Gold, B. \& Agraz, H. C. (2nd ed., pp. 157-176) Universidad Autónoma de Campeche, Universidad Nacional Autónoma de México, Instituto Nacional de Ecología.

Albert, A. L. (1996). Persistent pesticides in México. Reviews of Environmental Pollution, Contamination and Toxicology, 147, 1-44. 
Al-Ghadban, A. N., JaGon, P. G. \& Abdali, F. (1994). Total organic carbon in the sediments of the Arabian Gulf and need for biological productivity investigation. Marine Pollution Bulletin, 28, 356-362.

Allen-Gil, S. M., Gubala, C. P., Wilson, R., Landers, D. H., Wade, T. L., Sericano, J. L., \& Curtis, L. R. (1997). Organochlorine pesticide and polychlorinated biphenyls (PCBs) in sediments and biota from four U.S Arctic Lakes. Archives of Environmental Contamination and Toxicology, 33, 378-387.

ATSDR. (1994b). Toxicological Profile for 4,4'-DDT, 4,4'-DDE, 4,4'-DDD (Update). U.S. Dept. Health \& Human Services, Agency for Toxic Substances and Disease Registry. TP-93/05. pp. 166.

ATSDR. (2002). Toxicological profile for DDT, DDE, and DDD. Agency for Toxic Substances and Disease Registry. (ATSDR). Update. Atlanta, Georgia. U.S. Department of Health and Human Service. pp. 497.

Barlas, N.E. (1999). Determination of organochlorine pesticide residues in aquatic systems and organisms in Upper Sakarya Basin, Türkiye. EnvironmentalContamination and Toxicology, 62, 278-285.

Botello, A. V., Villanueva, S. \& Mendelewicz, M. (1990). Programa de vigilancia de los hidrocarburos organoclorados y de microorganismos patógenos específicos en lagunas costeras del Golfo de México. Informe anual 1989-1990 (pp. 69.). México, Proyecto OEA-CONACYT.

Botello, A. V., Rendón-Von, O. J., Gold-Bouchot, G. \& C. Agraz-Hernández. (2004). Golfo de México Contaminación e Impacto Ambiental: Diagnóstico y Tendencias, 2da Edición. Univ. A. de Campeche, UNAM, Instituto Nacional de Ecología. pp. 696.

Caballero, R. M. (2001). Diagnóstico Regional del uso del DDT y el control de la malaria. Informe Regional para México y Centroamérica Instituto de Salud y Ambiente México, 5-28.

Calva, B. L. G., Pérez, R. A. \& Márquez, G. A. Z. (2006). Contenido de carbono orgánico y características texturales de los sedimentos del sistema costero lagunar Chantutopanzacola, Chiapas. Hidrobiológica, 16 (2), 127-136.

Carta Nacional Pesquera. (2006). Publicada en el Diario Oficial el día viernes 25 de Agosto de 2006. [Online] Available: http://www.inapesca.gob.mx/index.php?option=com_content\&task=view\&id=124\&Itemid=124

Castañeda, L. O., \& Contreras, E. F. (1994). Serie: bibliografía comentada sobre ecosistemas costeros mexicanos (3). Golfo de México I (de Tamaulipas a Veracruz). (pp. 615) CONABIO/UAM-1/CDELM.

Castañeda, C. M. R. (2006). Evaluation des niveaux de contamination de l'huître Crassostrea virginica par le DDT et des mètabolites. Tesis Doctoral Université de Bretagne Occidentale, pp. 250.

CICOPLAFEST. (1994). Comisión Intersecretarial para el control del proceso y uso de plaguicidas y sustancias tóxicas. Catálogo Oficial de Plaguicidas. México D. F.

CICOPLAFEST. (2004). Comisión Intersecretarial para el control del proceso y uso de plaguicidas y sustancias tóxicas. Catálogo Oficial de Plaguicidas. México D.F.

Colborn, T., Vom Saal, F. S., \& Soto, A. M. (1993). Developmental effects of endocrine-disrupting chemicals in wildlife and humans. Environmental Health Perspectives, 101, 378-384.

COPs. (2004). Convenio de Estocolmo sobre Contaminantes Orgánicos Persistentes, Ginebra/Nairobi. [Online] Available: http://www.pops.int/documents/convtext/convtext_sp.pdf.

Díaz, B. F. (2000). Factores de exposición y toxicidad del DDT y de la Deltametrina en humanos y en vida silvestre. Informe técnico apoyado por la Comisión de Cooperación Ambiental de América del Norte. México.

Dzul, F. A, Penilla, R. P. \& Rodríguez, A. D. (2007). Susceptibilidad y mecanismos de resistencia a insecticidas en Anophelesalbimanus del sur de la Península de Yucatán, México. Salud pública México, 49 (4).

Extoxnet. (1993). Bioaccumulation. Extension Toxicology Network. [Online] Available: http://ace.ace.orts.edu/info/extoxnet/tibs/bioaccum.htm.

Extoxnet. (1993). Naled pesticide information profile. [Online] Available: http://pmep.cce.cornell.edu/profiles/extoxnet/metiram-propoxur/naled-ext.html

Farrington, J. W. (1983). Bivalves as sentinels of coastal chemical pollution: The mussel (and oyster) watch. Oceanus, 26, 18-29.

Fernández, C. J. (1988). Panorama histórico y epidemiológico del paludismo en México. Secretaría de Salud. México. 
Ferreira, A. M., \& Vale, C. (2001). Seasonal and inter-annual variation of PCB and DDT contents the oyster Crassostrea angulata from the Sado estuary (Portugal). Ciencias Marinas, 27 (2), 255-268.

Flores, C. C., \& Méndez, V. L. (1982). Contribución al conocimiento del Ictioplancton de la Laguna de Alvarado, Ver. Anales del Instituto de Ciencias del Mar y Limnología, 9 (1), 141-160.

Gamboa, R. H. (2008). Determinación de la concentración de contaminantes (plaguicidas organoclorados) en jaibas sp. en el sistema lagunar de Vega de Alatorre, Ver. Tesis Maestria Instituto Tecnologico de Boca del Río. pp. 150.

Gellert, R. J, Heinrichs, W. L. \& Swerdloff, R. S. (1972). DDT homologues: estrogen-likeeffectsonthe vagina, uterus and pituitary of the rat. Endocrinology, 91, 1095-1100.

Glynn, A. W., Granath, F., Aune, M., Atuma, S., Darnerud, P.O., Bjerselius, R., Vainio, H., \&Weiderpass, E. (2003). Organochlorines in Swedish women: determinants in serum concentrations. Environmental Health Perspectives, 111, 349-355.

Gold, B. G., Silva, H. T., \& Zapata, P. O. (1993). Chlorinated Pesticides in the Rio Palizada, Campeche, Mexico. Marine Pollution Bulletin, 26 (11), 648-65.

Gutiérrez, G., Flores, M., \& López, M. J. A. (1984). DDT en el ostión Crassostrea gigas (Thunberg) cultivado en Bahía San Quintín, Baja California. Ciencias Marinas, 10 (3), 17-30.

Gutiérrez, G., Flores, M. G., Villaescusa, C. J. (1988). Hidrocarburos clorados en moluscos del Valle de Mexicali y Alto Golfo de California. Ciencias Marina, 3, 91-113.

Hargrave, B. T., \& Philips, G. A. (1976). Residues in benthic invertebrates and demersal fishes in St. Margaret's Bay Nova Scotia. Journal of Fisher Research, 33, 1692-1696.

INAPESCA. (2009). Programa Nacional de Investigación Científica y Tecnológica en Pesca y Acuacultura. Informe Final, (pp. 57). México.

INEGI. (1999). Anuario estadístico del estado de Veracruz. In Instituto Nacional de Estadística Geografía e Informática (pp. 784). México.

IPCS. (1989). DDT and its derivatives-environmental aspects. Geneva, World Health Organization, International Programme on Chemical Safety. Environmental Health Criteria 83.

Jaga, K., \& Dharmani, Ch. (2003). Global Surveillance of DDT and DDE levels in human tissues. International Journal of Occupational and Environmental Health, 16, 7-20.

Jury, W. A., Spencer, W. F., \& Farmer, W. J. (1983). Use of models for assessing relative volatility, mobility and persistence of pesticides and other trace organics in soil systems, in Hazard Assessment of Chemicals. Academic Press Inc. (Vol. 2, pp. 1-43). San Diego California, USA.

Kennish, M. J., \& Ruppel, B. E. (1996). DDT Contamination in Selected Estuarine and Costal Marine Finfish and Shellfish of New Jersey. Institute of Marine and Coastal Sciences, Rutgers University, New Brunswick, New Jersey 08903, USA.

Larson, P., Berglund, O., Backe, C., Bremle, G., Eklov, A., Jarnmark, C., \& Persson, A. (1995). DDT-Fate in tropical and temperate regions. Naturwissenschaften, 82, 559-561.

Ley General del Equilibrio Ecológico y la Protección al Ambiente. (1988). Publicada en el Diario Oficial de la Federación el 28 de enero de 1988. Comisión Nacional de Áreas Naturales Protegidas, pp. 97.

Lowe, J. I., Wilson, P. D., Rick, A. J., \& Wilson, A. J. (1971). Chronic exposure of oysters to DDT, toxaphene and parathion. Proceedings of the National Shellfisheries Association, 61, 71-79.

Marchand, M., \& Duursma, E. K. (1976). Levels of PCBs and DDTs in mussels from the NW Mediterranean. Marine Pollution Bulletin, 7, 65-69.

Matthies, M., Behrendt, H., \& Trapp, S. (1991). Modelling and model validation for exposure assessment of the terrestrial environment in Pesticide Chemistry. ed. Verlan Chemie, (pp. 433-444). New York, USA.

Murphy, P.G. (1972). Sulfuric acid for the cleanup of animal tissues for analysis of acid-stable chlorinated hydrocarbon residues. Journal of the Association of Official Analytical Chemists, 55, 1360-1362.

NOM-031-SSA1-1993. Norma Oficial Mexicana. Límites Máximos Permisibles de Contaminantes para productos de la Pesca como moluscos bivalvos frescos y refrigerados; además de la metodología para la 
determinación de Vibrio cholerae. Publicada en el Diario Oficial de la Federación el 6 de Marzo de 1995. México, D.F.

Páez, O. F., Guerrero, G. S. R., \& Ruíz, F. A. C. (1998). The environmental impact of shrimp aquaculture and the coastal pollution in México. Marine Pollution Bulletin, 36 (1), 65-75.

Pardío, T., Waliszewski, N., Landín, A., \& Bautista, G. (2003). Organochlorine pesticide residues in cow's milk from a tropical region of Mexico. Food Additives and Contaminants, 20, 259-269.

Pellerin, J. M. (1992). L'evolution des conditions physiologiques de Crassostrearhizophorae en foction des niveaux de bioaccumulation et du gradient de pullution'. Deuxième Conference Internationale Second International Conferenc. Purification des Coquillages Shellfish Depuration.

Phillips, D. J. H., \& Rainbow, P. S. (1994). Biomonitoring of Trace Contaminants. J. Cairns. Chapman and Hall, London, pp. 371.

Plimmer, J. (1992). Dissipation of pesticides in the environment in Fate of pesticides \& Chemicals in the environment, Ed. J. Schnoor. Environ. Sci. Tech. Wiley-Interscience Series, 79-90.

Rosales, M. T. L., Botello, A. V., \& Mandelli, E. F. (1979). PCB'S and organoclorine insecticides in oyters from coastal lagoons of the gulf of Mexico. Bulletin of Environmental Contamination and Toxicology, 21, 652-656.

SSA. (1997). Programa para el control de vectores de la Jurisdicción Sanitaria No. VIII. Dirección General de Epidemiología. Indicadores de paludismo en Veracruz y a nivel nacional. Secretaria de Salud (SSA)

Sericano, J. L., Wade, T. L., Atlas, E. L., \& Brooks, J. M. (1990)a. Historical perspective on the environmental bioavailability of DDT and its derivatives to Gulf of Mexico oysters. Environmental Science and Technology, 24 (10), 1541-1548.

Sericano, J. L., Atlas, E. L., Wade, T. L., \& Brooks, J. M. (1990). NOAA's Status and Trends Mussel Watch Program: Chlorinated pesticides and PCBs in oysters (Crassostrea virginica) and sediments from the Gulf of Mexico, 1986-1987. Marine Environmental Research, 29, 161.

Sericano, J. L., Wade, T. L., Jackson, T. J., Brooks, J. M., Tripp, B. W., Farrington, J. W., Mee, L. D., Readmann, J. W., Villeneuve, J. P., \& Goldberg, E. D. (1995). Trace organic contamination in the Americas: an overview of the US national status and trends and the international 'Mussel Watch' programmes. Marine Pollution Bulletin, 31, 4-12, 214-225.

Snedeker, S. (2001). Pesticides and breast cancer risk: a review of DDT, DDE and dieldrin. Environmental Health Perspectives, 109 (1), 35-47.

Sonowane, B. R. (1995). Chemical contaminants in human milk: An overview. Environmental Health Perspectives, 103 (6), 197-205.

Soto, A. M., Sonneschein, C., Cheng, K. L., Fernandez, M. F., Olea, N., \& Serrano, F. O. (1995). The E-screen assays as tool to identify estrogens: an update on estrogenic environmental pollutants. EnvironmentalHealthPerspectives, 103, 113-122.

SSA. (2003). Secretaría de Salud. Normas Oficiales Mexicanas. [Online] Available: http://www.salud.gob.mx/unidades/dgaj/

Stapleton, F. H. (1998). The dawn of DDT and its experimental use by the Rockefeller foundation in Mexico. 1943-1952. Parasitological, 40, 149-158.

Syasina, I. G. (2003). Organochlorine Pesticides in Fishes and Mollusks from Lower Reaches of the Tumen River and of the Contiguous Part of Peter the Great Bay (Sea of Japan). Russian Journal of Marine Biology, 29 (1), 23-30.

Tirpenou, A. E., Tsigouri, A. D., \& Gouta, E. H. (1998). Residues of organohalogen compunds in various dolphin tissues. Bulletin Environmental Contamination Toxicology, 60, 216-224.

Waliszewski, S. M., Pardio, S. V. T., Chantiri, P. J.N., Infanzón, R. R. M., \& Rivera, J. (1995). Evaluación de los niveles de DDT y HCH en el tejido adiposo de algunas personas fallecidas en el estado de Veracruz, México. Revista internacional de contaminación ambiental, 11, 87-93.

Waliszewski, S. M, Pardio, V. T., Chantiri, J. N., Infanzon, R. M. \& Rivera, J. (1996). Organochlorine pesticide residues in adipose tissue of mexicans. Science of the Total Environment, 181, 125-131.

Waliszewski, S.M., Aguirre, A.A., Infanzón, R.M., \& Siliceo, J. (2000). Carry-over of persistent organochlorine pesticide through placenta to fetus. Revista de Salud Pública de México, 42, 384-390. 
Waliszewski, S. M., Meza, H. M. V, Infanzón, R. M., Trujillo, P. \& Morales, G. M. (2003). Niveles de plaguicidas organoclorados persistentes en mujeres con Carcinoma mamario en Veracruz. Revista internacional de contaminación ambiental, 19 (2), 59-65.

Waliszewski, S. M., Mójica, G. X., Infanzón, R. M., Barradas, D. C. M., \& Carvajal, Z. O. (2008). Uso del ácido sulfúrico en las determinaciones de plaguicidas organoclorados. I. Calidad químico-analítica de la preparación de grasas por el ácido sulfúrico Concentrado. Revista Internacional de Contaminación Ambiental, 24 (001), 33-38.

Wang, Z. W., Yan, J., \& Chi, Z. G. (2008). Spatial and vertical distribution of organochlorine pesticides in sediments from Daya Bay, South China. Marine Pollution Bulletin, 56, 1578-1585.

Wolff, M., Zeleniuch, J. A., Dubin, N., \& Toniolo, P. (2000). Risk of breast cancer and organochlorine exposure. Cancer Epidemiology, Biomarkers \& Prevention, 9, 271-277.

WHO. (1984). Chemical methods for the control of arthropod vectors and pests of public health importance. World Health Organization (WHO), Geneva.

Young, D. R., Grossett, R. W., \& Heesen, T. C. (1988). Persistence of chlorinated hydrocarbon, contamination in California marine ecosystem. In: Wolfe D.A., O’Connor T.P. (Eds). Coastal Processes in Marine Pollution, $33-41$.

Zumbado, M., Goethals, M., Álvarez, E. E., Luzardo O. P., Serra, L., Cabrera, F., \& Domínguez, B. L. (2004). Exposición inadvertida a plaguicidas organoclorados (DDT y DDE) en la población de las Islas Canarias. Ecosistemas, 13 (3), 51-58.

Table 1. Mean concentrations ( \pm standard deviations) of DDT and its metabolites (ng/g, lipid base) in oysters, $C$. virginica, collected September 2001 through September 2002, from La Mancha and Alvarado lagoons (value ranges in parentheses; nd=not detected).

\begin{tabular}{|l|c|c|c|c|c|c|}
\hline \multirow{2}{*}{ Pesticide } & \multicolumn{2}{|c|}{ Summer } & \multicolumn{2}{c|}{ Winter } & \multicolumn{2}{c|}{ Spring } \\
\cline { 2 - 7 } & Alvarado & La Mancha & Alvarado & La Mancha & Alvarado & La Mancha \\
\hline \multirow{2}{*}{ pp'- DDE } & $12.230 \pm 5.160^{\mathrm{a}}$ & $38.130 \pm 3.100^{\mathrm{b}}$ & $20.450 \pm 3.550^{\mathrm{a}}$ & $31.720 \pm 2.240^{\mathrm{b}}$ & $20.390 \pm 1.160^{\mathrm{a}}$ & $48.860 \pm 3.040^{\mathrm{b}}$ \\
& $(3.070-17.870)$ & $(18.700-91.500)$ & $(5.640-47.170)$ & $(5.400-58.500)$ & $(2.570-48.630)$ & $(27.600-97.400)$ \\
\hline pp'-DDD & $8.500 \pm 5.140^{\mathrm{a}}$ & $24.330 \pm 13.760^{\mathrm{b}}$ & $10.690 \pm 0.670^{\mathrm{a}}$ & $29.780 \pm 4.900^{\mathrm{b}}$ & $11.160 \pm 6.020^{\mathrm{a}}$ & $17.500 \pm 0.980^{\mathrm{a}}$ \\
& $(1.007-19.020)$ & $(7.050-38.970)$ & $(0.003-25.100)$ & $(0.003-95.900)$ & $(2.630-21.360)$ & $(0.003-38.600)$ \\
\hline pp'-DDT & $4.407 \pm 1.462^{\mathrm{a}}$ & nd & $1.044 \pm 0.948^{\mathrm{a}}$ & $\mathrm{nd}$ & $2.590 \pm 0.323^{\mathrm{a}}$ & nd \\
& $(3.160-37.940)$ & & $(0.001-8.340)$ & & $(0.001-20.710)$ & \\
\hline \multirow{2}{*}{ op'-DDT } & $16.290 \pm 11.050^{\mathrm{a}}$ & $45.100 \pm 6.380^{\mathrm{b}}$ & $28.890 \pm 2.940^{\mathrm{a}}$ & $12.110 \pm 5.680^{\mathrm{b}}$ & $25.040 \pm 7.370^{\mathrm{a}}$ & $50.860 \pm 7.670^{\mathrm{b}}$ \\
& $(3.160-37.940)$ & $(9.000-83.100)$ & $(0.002-67.300)$ & $(0.002-35.150)$ & $(2.510-57.290)$ & $(21.300-106.100)$ \\
\hline E-DDT & $41.430 \pm 2.110^{\mathrm{a}}$ & $107.570 \pm 5.630^{\mathrm{b}}$ & $61.070 \pm 5.620^{\mathrm{a}}$ & $73.610 \pm 2.100^{\mathrm{b}}$ & $59.180 \pm 3.570^{\mathrm{a}}$ & $117.230 \pm 8.460^{\mathrm{b}}$ \\
& $(7.300-77.420)$ & $(20.580-71.300)$ & $(16.900-25.200)$ & $(5.400-18.400)$ & $(9.300-127.300)$ & $(67.300-242.100)$ \\
\hline
\end{tabular}

Means with different superindices are statistically different $(P<0.05)$ among lagoons within seasons. 
Table 2. Mean concentrations ( \pm standard deviations) of DDT and its metabolites (ng/g, lipid base) in oysters, $C$. virginica, collected January - December 2005, from Tamiahua and Vega de Alatorre lagoons (value ranges in parentheses).

\begin{tabular}{|c|c|c|c|c|c|c|}
\hline \multirow[b]{2}{*}{ Pesticide } & \multicolumn{2}{|c|}{ Winter } & \multicolumn{2}{|c|}{ Spring } & \multicolumn{2}{|c|}{ Summer } \\
\hline & Tamiahua & Vega de Alatorre & Tamiahua & Vega de Alatorre & Tamiahua & Vega de Alatorre \\
\hline $\begin{array}{l}\text { pp'- } \\
\text { DDE }\end{array}$ & $\begin{array}{l}25.280 \pm 5.605^{\mathrm{ac}} \\
(19.040-30.820)\end{array}$ & $\begin{array}{c}17.187 \pm 8.513^{c} \\
(10.324-28.100)\end{array}$ & $\begin{array}{l}41.212 \pm 11.851^{\text {bd }} \\
(32.182-57.142)\end{array}$ & $\begin{array}{l}24.060 \pm 6.999^{\text {ac }} \\
(16.323-32.542)\end{array}$ & $\begin{array}{l}34.212 \pm 10.411^{a b} \\
(23.641-48.112)\end{array}$ & $\begin{array}{l}52.878 \pm 15.996^{\mathrm{d}} \\
(40.862-76.430)\end{array}$ \\
\hline pp'-DDD & $\begin{array}{c}18.792 \pm 6.248^{\mathrm{a}} \\
(15.220-28.123)\end{array}$ & $\begin{array}{l}16.342 \pm 7.165^{\mathrm{a}} \\
(9.374-26.184)\end{array}$ & $\begin{array}{l}13.417 \pm 3.579^{a b} \\
(10.129-18.136)\end{array}$ & $\begin{array}{c}8.399 \pm 2.339^{b} \\
(5.936-11.376)\end{array}$ & $\begin{array}{c}17.458 \pm 5.966^{\mathrm{a}} \\
(11.128-22.900)\end{array}$ & $\begin{array}{c}12.837 \pm 4.656^{\mathrm{ab}} \\
(8.040-18.146)\end{array}$ \\
\hline pp'-DDT & $\begin{array}{l}5.780 \pm 1.208^{\mathrm{ac}} \\
(4.196-7.018)\end{array}$ & $\begin{array}{l}5.238 \pm 2.288^{\mathrm{ac}} \\
(2.983-7.542)\end{array}$ & $\begin{array}{l}13.628 \pm 4.563^{\text {be }} \\
(10.224-20.213)\end{array}$ & $\begin{array}{l}2.042 \pm 0.407^{\mathrm{a}} \\
(1.548-2.421)\end{array}$ & $\begin{array}{l}8.626 \pm 2.928^{\mathrm{cd}} \\
(6.282-12.862)\end{array}$ & $\begin{array}{c}12.629 \pm 4.494{ }^{\mathrm{de}} \\
(6.325-16.330)\end{array}$ \\
\hline op'-DDT & $\begin{array}{l}49.409 \pm 7.796^{\mathrm{a}} \\
(37.900-55.182)\end{array}$ & $\begin{array}{l}33.091 \pm 11.215^{\mathrm{a}} \\
(22.724-44.800)\end{array}$ & $\begin{array}{l}35.223 \pm 10.751^{a} \\
(23.824-46.361)\end{array}$ & $\begin{array}{l}41.654 \pm 13.818^{\mathrm{a}} \\
(33.540 \pm 62.32)\end{array}$ & $\begin{array}{l}39.450 \pm 9.783^{\mathrm{a}} \\
(29.624-52.188)\end{array}$ & $\begin{array}{l}34.076 \pm 21.640^{\mathrm{a}} \\
(10.724-59.324)\end{array}$ \\
\hline$\sum$-DDT & $\begin{array}{l}99.258 \pm 8.508^{a b} \\
(87.641-106.861)\end{array}$ & $\begin{array}{c}86.041 \pm 31.626^{\mathrm{a}} \\
(64.022 \pm 132.986)\end{array}$ & $\begin{array}{l}125.542 \pm 34.670^{a b} \\
(104.237-177.335)\end{array}$ & $\begin{array}{l}87.216 \pm 13.081^{\mathrm{a}} \\
(87.334-102.465)\end{array}$ & $\begin{array}{c}119.410 \pm 44.594^{\mathrm{ab}} \\
(94.469-186.124)\end{array}$ & $\begin{array}{l}138.293 \pm 36.555^{b} \\
(115.351-192.834)\end{array}$ \\
\hline
\end{tabular}

Means with different superindices are statistically different $(P<0.05)$ among lagoons within seasons.

Table 3. $p p^{\prime}$-DDT/ $p p$ '-DDE values from oysters, Crassostrea virginica, as a function of mean annual values in the four lagoons studied (nd=not detected).

\begin{tabular}{|l|c|c|c|c|c|c|c|}
\hline Lagoon & $\begin{array}{c}o p^{\prime}-\mathrm{DDT} \\
(\mathrm{ng} / \mathrm{g})\end{array}$ & $\begin{array}{c}p p^{\prime}-\mathrm{DDD} \\
(\mathrm{ng} / \mathrm{g})\end{array}$ & $\begin{array}{c}p p^{\prime}-\mathrm{DDE} \\
(\mathrm{ng} / \mathrm{g})\end{array}$ & $\begin{array}{c}p p^{\prime}-\mathrm{DDT} \\
(\mathrm{ng} / \mathrm{g})\end{array}$ & $\begin{array}{c}p p^{\prime} \text {-DDT/ } \\
p p^{\prime}-\mathrm{DDE}\end{array}$ & $\begin{array}{c}\text { Mean } \\
\Sigma \mathrm{DDT} \\
(\mathrm{ng} / \mathrm{g})\end{array}$ & Area (ha) \\
\hline Tamiahua & 41.361 & 16.556 & 33.568 & 9.345 & 0.278 & 114.737 & 88000.00 \\
\hline $\begin{array}{l}\text { Vega de } \\
\text { Alatorre }\end{array}$ & 36.274 & 12.526 & 31.375 & 6.636 & 0.212 & 103.850 & 2250.00 \\
\hline Alvarado & 23.407 & 10.117 & 17.690 & 2.680 & 0.152 & 53.893 & 11800.00 \\
\hline La Mancha & 36.023 & 23.870 & 39.570 & $\mathrm{nd}$ & 0.000 & 99.470 & 156.74 \\
\hline
\end{tabular}

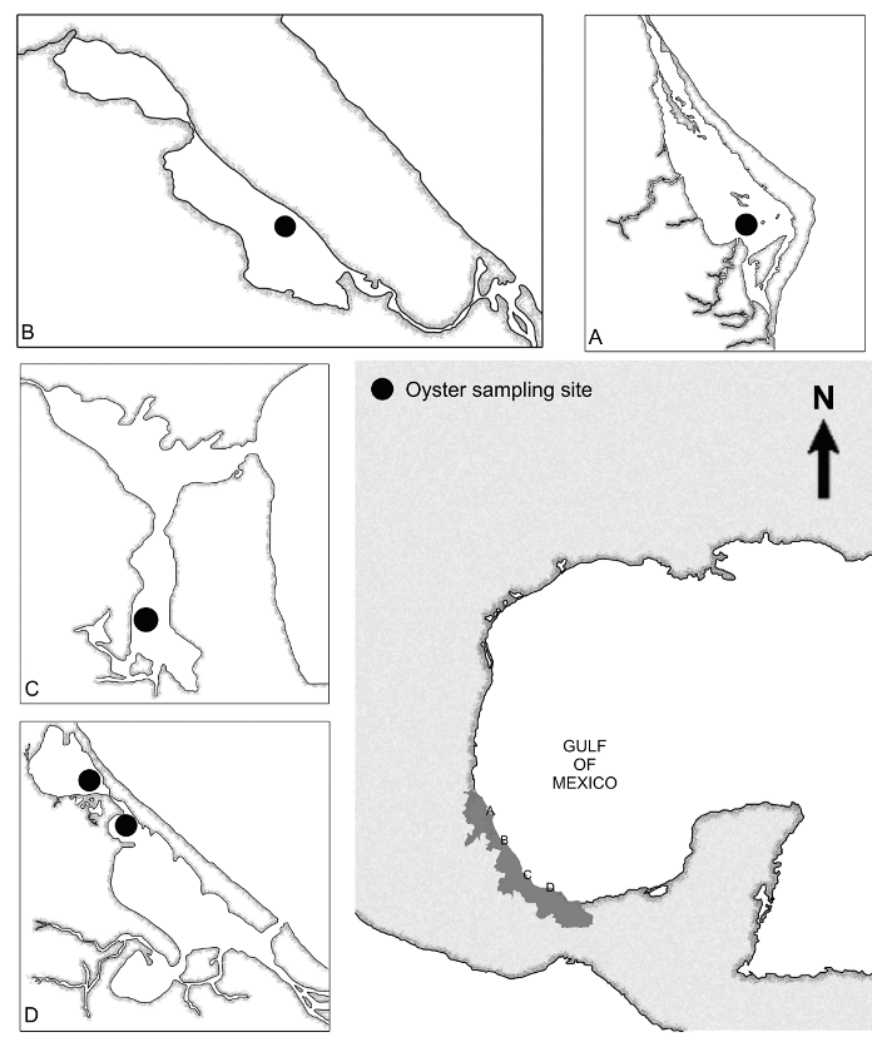

Figure 1. Lagoon systems in the state of Veracruz used for oyster collection in this study: A) Tamiahua; B) Vega de Alatorre; C) La Mancha; and D) Alvarado 